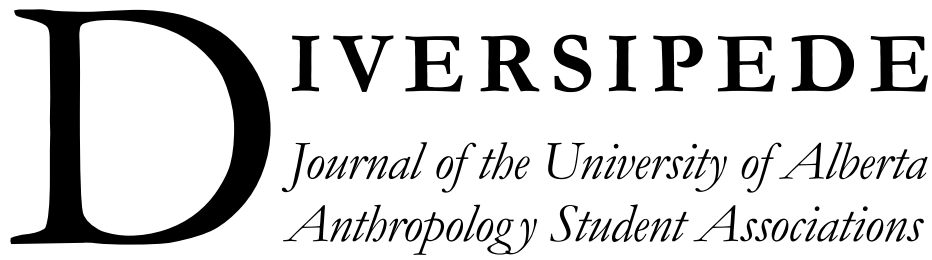

Volume 1

May 2012

Number 2

\section{Get That Camera Outta My Face: Ethics in Documentary Media}

\section{Matthew Hayes}

$\mathrm{I}^{\mathrm{n}}$ n 2011, I completed a film project for a graduate seminar on ethnographic methodology. The exercise involved three hours of observant participation (Tedlock 1991; see also Castañeda 2006, 95-96), during which I set up my camera on a tripod in three different locations for an hour in each, in front of a sign that read: "If you wish to be in a film, please stand here." An arrow pointed down to the spot directly in front of the lens. I waited to see what would happen, and the results, frankly, surprised me. ${ }^{1}$ What were most unexpected were the particular ethical considerations that arose. Among others, the opportunity for self-presentation (MacDougall 1992, 97); the significance of ethnographic refusal (Simpson 2007); and the (largely unfulfilled) promise of reciprocity (Jackson 2005,169-170; Mauss 1990 [1950]).

This exercise led me to rethink my priorities when using visual methods to conduct research. I argue that, particularly in mainstream public consciousness, a major focus of the filmmaker while making and editing a film is placed on how well it will screen with the audience, and perhaps how much revenue it will produce (see Winston 2000). While this often coheres with the fact that most documentary films struggle to simply break even at the box office (if they make it there in the first place), I think this focus is misplaced. Instead, I argue that more focus should be put back upon the participants of a film study: the subjects in front of the camera. This idea is in no way radical. It should be a first principle of carrying out social research: do no harm, and ensure the welfare of your subjects. However, I also think it is very rarely carried out to its fullest these days. The important point here is that the issues I raise in this paper do not apply solely to visual anthropology or the practice of using visual methods. They apply to all social scientific research, regardless of the scope (see Grimshaw 2011, 257). It is simply that, as I have noticed since I began using film, visual methods tend to make explicit many of the issues inherent in all social scientific research.

The issues I encountered while conducting the above-mentioned exercise made me aware of what exactly I was hoping would happen: I wanted streams of people lining up to sing and dance in front of my camera. I wanted action! As Simpson (2003, 105) writes: "Anthropology is a practice of desire." I desired for these things to happen,

\footnotetext{
${ }^{1}$ The concept was inspired by the last scene in David and Judith MacDougall's Photo Wallahs (1991). The seminar was taught by my supervisor Dara Culhane. The finished film based on the exercise can be viewed here: http://vimeo. com/24566964.
}

Graduate student, Department of Sociology and Anthropology, Simon Fraser University Author contact: mrhayes@sfu.ca

Diversipede, Vol. 1, No. 2, pp. 1-11, 2012 
to prove to myself (and to prove a previous theory I held), that people in fact love being on camera. I was hoping this was true and was disappointed at times when this action did not occur. However, this disappointment was useful (Simpson 2007, 78). I realized that my goal should never have been to wish for dancing monkeys; this was unethical. At the expense of the agency of my imagined participants, I was too focused on the finished product and what kind of entertainment the viewer would see in the finished film. I should have initially placed my emphasis on ensuring that I do no harm to my participants, focusing on what they wanted from the exercise, not what $I$ wanted (see MacDougall 1994). Thankfully, I do not believe I caused any harm. At least, no one angrily told me to get my camera out of his or her face. But this holds an important lesson, which I outline in this paper. I trace a history of documentary film in order to highlight from where some of this attitude of privileging the audience has come, and where filmmaking perhaps should have gone instead. Priorities need to shift. I think by doing so social researchers, including myself, can make more ethical use of documentary media.

\section{FLAHERTY'S RECONSTRUCTIONS}

I begin almost at the very beginning, with an example from Robert Flaherty. In 1922 he produced the world's first commercially successful feature-length documentary film, Nanook of the North (see Ruby 2000, 67). Flaherty was neither an anthropologist, nor was he in any way trained as a filmmaker. He was actually an American mining prospector who was conducting research in Northern Quebec for his employer prior to making the film (Grimshaw 2001, 47; Ruby 2000, 7). He ended up building relationships there with the people who later featured in Nanook (one of whom was his indigenous wife!). Flaherty's path to a filmmaking career seems somewhat typical of many ethnographic filmmakers. It seems that only recently have filmmakers of this type actually been trained as anthropolo- gists. Most of the filmmakers who produced the body of work from which major aspects of visual anthropology developed were outside of the discipline altogether. Indeed, many of the most radical innovations and advancements in the discipline have come from either outsiders or "rebels" within the field, such as Jean Rouch and John Marshall (MacDougall 1998, 67).

Flaherty and his films have caused a great deal of debate over the years since their release (see Pink 2006, 24). Before his death in 1951, he had made, in addition to Nanook, two lesser-known documentaries of similar quality: Moana (1926) and Man of Aran (1934). The debate about these films often concerns the fact that everything, or nearly everything, in his films was staged (see Pink 2006, 23; Banks 2001, 148). The people are real and the places in which he shot are real, but all the scenes were planned out and scripted ahead of time. These "fabrications" were largely due to the technology available at the time: hand-crank powered cameras with no capacity for recording sound. These early film cameras had to be continually mounted on tripods because they were so heavy and awkward. This early technology did not allow the filmmaker to go mobile with the camera and follow the action like we can today with lighter, handheld camcorders. As was the standard at the time (see Winston 2000, 20), Flaherty thus had no choice but to reconstruct and dramatize the scenes for his film, simply because the camera was not mobile and flexible enough to do otherwise.

Two examples may suffice here to indicate the lengths that Flaherty at times had to go to in order to get his shot. There is a scene in Nanook in which the title character goes ice fishing and while holding his line, is thrown around on the ground by the seal that is apparently fighting for its life under the ice. The subsequent documentary film Nanook Revisited (Massot 1990) reveals that Flaherty actually had two holes cut in the ice, with a fishing line threaded from one hole 
underneath to the other. While Nanook was pulling on the line from one end, two men were pulling on it from the other, causing his titanic struggle and the ensuing hilarity of the scene. A more infamous scene from the film is that of Nanook (whose real name was Allakariallak) and his family preparing for the night in an igloo. We see them get undressed, settling comfortably into their blankets. The igloo was actually built about three times as large as it normally would have been, and it was halved (Barbash and Taylor 1997, 25). Rather than being a full dome, only half of it was built, in order to let in enough light for the camera to record. Flaherty had attempted to film in a regular sized igloo, but it proved too dark and cramped to produce any footage that he deemed viewable. So he had Nanook build half of a giant igloo instead.

Many have criticized Flaherty for this approach. The American filmmaker Emile de Antonio has remarked: "The charm and power of [Flaherty's] camera are marred by distortions, lies, and inaccuracies which pander to a fake romantic, fake nature-boy view of society" (cited in Barbash and Taylor 1997, 25). It has been said that Flaherty's films were lies because he used reconstruction, because he set up the scenes he filmed as in a fiction film, and because he did not actually film his participants like a documentarian "should". He also at first did not reveal to his audience the way in which he created the film, leaving them to believe what they were seeing was "authentic" Inuit life. Many of those criticizing Flaherty and his films say that he misled his audience and did not in fact portray the "truth". Because of the staged scenes, the documentary was in fact a fiction and did not represent what a documentary should be: it did not show real life; it did not show the truth. Thus, the criticism against Flaherty and his films, against reconstruction and the manipulation of footage in documentary media, rests on ontological and epistemological assumptions about what documentary is and how it produces knowledge.
I argue quite the opposite of critics like Antonio. I think that anyone who criticizes a documentary for telling lies or not telling the truth because it has, for example, used reconstruction or has not let the action unfold as it "normally" would, or has not used "natural" light, retains a misguided view of what documentary is in practice, and how it started. I think these critics do not fully understand what documentary is for and how a documentary film is produced (see Winston 2000). Fieldwork and the use of visual methods involve selection. It inevitably occurs, as you cannot record everything and you cannot report on everything when the project is complete, whether in a book, article, film, photo essay, memoir, etc. There is a bit of a paradox here, an irony. Every documentary film is a subjective interpretation of the filmmaker's view of the world. This has been acknowledged now in academic circles, but is ironically the very realization that caused so much criticism of documentary film not long after its invention (MacDougall 2006, 228; also see Malinowski 1967, 22). This realization is also why I believe so many people have criticized Flaherty's films, and why the general public can sometimes take offence with documentaries that reconstruct events, and therefore apparently "lie" to them (Winston 2000).

\section{SCIENTIFIC Origins}

Here I backtrack a bit, because I want to emphasize the use that film and photography were initially put to in the social sciences. This was a scientific, positivistic use. The camera was thought of simply as a good recording device, a machine that could produce objective pictures of observable phenomena, which one could later look back to for confirmation of what occurred that day, at that time, in that place. The camera could be used to record unmediated "reality". The underlying idea was that a camera was a mirror held up to the world. This underlying idea did not recognize that the person holding the mirror holds it in a very specific way that af- 
fects what the mirror shows. Especially in public perceptions of documentary media, this notion of the camera portraying "real life" still exists, despite the evidence we now cite against it.

The first significant use of a camera in this positivistic sense was in 1877 by the Englishman Edward Muybridge, who was working in San Francisco at the time of his experiment (MacDougall 1998, 126, 138). He used photography in an attempt to solve the most frustrating scientific question of the day: did a horse have all four hooves off the ground at once while galloping? After being commissioned to solve this riddle, he set up on a racetrack a series of cameras rigged to tripwires, which the galloping horse activated as it moved along (Gray 2010, 4). This series of photos clearly displayed the answer to the riddle: the horse did indeed have all four hooves off the ground at once! So the camera became useful as a scientific measure of body movement and the natural world, resonating with early anthropology's fascination with physical (read: racial) traits.

Fifty years later, Margaret Mead, working with her third husband Gregory Bateson, produced a monumental photographic study of Balinese body techniques entitled Balinese Character (1942). As a result, Mead concluded that one could produce objective images of individuals if one simply left a camera running (see Bateson and Mead 1976). Yet Mead's assumption reveals a fundamental misunderstanding of how cameras work. ${ }^{2}$ She forgot that there was nothing objective about choosing to leave the camera running untouched while it was pointed at, for instance, a group of children, rather than a group of adults. Someone was still pointing the camera and making selections based on a subjective interpretation of what was happening in front of the lens. However, Mead maintained confidence in the use of the camera as an objective aid to social scientific research right up until her death (e.g. Mead 2003 [1974]) and indeed, this notion still persists today. These assumptions of objectivity stand in stark contrast to Flaherty's own uses of the camera. He had no qualms about manipulating-some would pronounce it "tampering" — with his subjects and the subsequent footage. Flaherty put into practice an entirely different set of ontological and epistemological principles. He knew the camera was as fallible as any individual human's vision and so he accordingly exemplified a more subjective and participatory approach to filmmaking, one that is largely unacknowledged as the predecessor of much later attempts (Pink 2006, 24; Ruby 2000, 83).

\section{New Technology, New Practice}

To jump ahead: in the 1960s in America, this notion of the camera recording unmediated reality gained strength. It is believed the camera can record "truth", even while it is handheld and mobile. Brian Winston (2000, 21-22), a British documentary theorist and journalist, traces to this decade what he considers to be a major turning point in the practice of producing visual media. This turning point arose as a direct result of new technology: smaller, lighter, handheld camcorders and, even more importantly, the capacity for recording synchronous sound. All of a sudden, documentary filmmakers could go out onto the street and record both video and audio of their subjects without having to create soundtracks in the studio in postproduction. They could record people's voices as it happened. As a result, two major movements developed: cinéma vérité and direct cinema.

The definitions of these movements I find most satisfactory are found in Brian Winston's book Lies, Damn Lies and Documentaries (2000, 169 note 2), which provides a cursory indication of the subject matter. Cinéma vérité is a reflexive mode of filmmaking whereby the process of filmmak-

${ }^{2}$ What Grimshaw $(2011,248)$ calls her "simple-minded scientism". 
ing itself is made apparent to the audience. Films of this type may include footage of the cameraman and audio recorder (Loizos 1997, 94), the filmmakers themselves asking people questions, and most importantly declaration (explicit or otherwise) of the use of reflexive principles in the making of the film from the start (MacDougall 1998, 89-91; see also Strathern 1987). ${ }^{3}$ These types of films attempt to include some of the elements that you would need to see in order to understand how the film was made. Cinéma vérité goes even further at times by making the very act of filmmaking the subject of the film itself, rather than just a part of the film seen alongside a different subject. The classic exemplar of this is the film by Edgar Morin and Jean Rouch: Chronique d'un été (1960). Others include many of the Yanomamö films by Timothy Asch and Napoleon Chagnon, such as The Ax Fight (1975).

Direct cinema, on the other hand, is quite distinctly American. This latter approach is observational: a filmmaker using it may claim to be a fly-on-the-wall, privileging the action unfolding before the camera, while attempting to maintain distance from this action (Winston 2000, 169 note 2). Direct cinema presumes that one can actually film something without interfering or affecting whatever it is being filmed. ${ }^{4}$ Thus it tends to carry on the positivistic goal of objectivity in filmmaking arising in the work of Muybridge and other early practitioners. Several examples include Robert Gardner's Forest of Bliss (1985), set in Benares, India, and the betterknown works by Albert and David Maysles, such as Salesman (1969), and Frederick Wiseman's Hospital (1970).

Whereas earlier filmmakers like Flaherty had to set up all shots with the camera on a tripod, the filmmakers of the 1960s could take the camera in their hands and on their shoulders into the field and record action as it unfolded, without a script. As a result, many filmmakers could now record intimate moments in peoples' lives, apparently without interference. One could crouch in the corner of a bedroom and film undisturbed, such as what Canadian filmmaker Allan King (1969) seemingly accomplished with $A$ Married Couple (see also Druick 2010). All of a sudden, the camera was a mirror, projecting unmediated, scientific reality, at least for some. Others felt differently. Especially in Europe, as a result of the prolific ethnographic filmmaker Jean Rouch, the more dominant feeling was that an observational approach was misguided and unethical, as the very act of filming changed behaviour. Having a camera in the room meant the scene was not unmediated, but that the camera was probably the main event in the first place. In some ways this latter movement tends to carry on the pioneering work of Flaherty, who from the start practiced a participatory approach, albeit behind the scenes, by showing Nanook the daily rushes and eliciting his feedback and suggestions for the next day's filming (Barbash and Taylor 1997, 24; Pink 2006, 24). Reflexivity and participation have always been as much a part of anthropological filmmaking (and ethnography in general!) as observation, even if it is not widely recognized. As the film critic James Hoberman rhetorically asks: "Who is more self-conscious than an anthropologist with a movie camera?" (cited in Barbash and Taylor 1997).

\section{What the Mainstream LoOKs Like}

I have attempted to trace a brief and specific history of documentary film suited to the purposes of this paper. I now present three "mainstream" examples that illustrate some of the concrete ethical dilemmas that those using visual methods have encountered and which indicate what I consider to be more ethical priorities in filmmaking. Canonical ethnographic films can be difficult to ac-

\footnotetext{
${ }^{3}$ Jay Ruby, in this regard, distinguishes between "films about anthropology" and "anthropological films" (1975:109).

${ }^{4}$ For a humourously cynical portrayal of this belief, see Weinberger (1994, 3-4).
} 
cess and so I hope these more popular films will resonate with contemporary audiences. I use the term "mainstream" loosely, to refer to films that have had either theatrical distribution and accessibly-priced DVD releases, and/or have had a successful run through the popular film festival circuit.

\section{Winnebago Man}

The first is Ben Steinbauer's Winnebago Man (2009). The film is about Jack Rebney, a Winnebago salesman, who is what some would call the "hero" of a viral video featuring outtakes of his quite energetic and enraged profanities used while shooting an industrial sales video. The film raises significant interest over reflexivity in the relationship between the filmmaker and the subject. Steinbauer features in the film as much as Rebney, if not more. The film is just as much about the filmmaker's personal experience dealing with Rebney as it is about the Winnebago salesman. What is particularly interesting is that the film raises the ethical dilemma that Steinbauer encounters over exposing this man to even more publicity through the making of this documentary. After leaving his job as a Winnebago spokesman, Rebney, also a former corporate news producer, secluded himself in a cabin in Northern California and cut virtually all ties with his past and what he considers morally depraved civilization. It took Steinbauer some time to track Rebney down and the filmmaker seems to understand the irony in making one last film about him and his infamy. This is particularly significant considering the trailer and the film both feature Rebney stating to Steinbauer and his filmmaking crew: "If you don't like it, pack up. Get the fuck out." Indeed, the film begins with the quote and works it into the climax. In terms of the polarization of observational and reflexive filmmaking, ${ }^{5}$ it is fascinating that the film documents this part of the filmmaking process as an integral aspect of the relationship. It is safe to say that the film raises perhaps the most fundamental question when using visual methods: is it ethical to even use them at all? It may be the case that they are entirely inappropriate, particularly if the subject of the film has past experience, negative or otherwise, with visual methods, such as Rebney did in several capacities. This dilemma may involve scrapping a project altogether.

Considering Rebney's past, the question is: should Steinbauer have made the film at all? A criticism could be leveled that this decision is the difference between producing an admittedly hilarious portrait of "the angriest man in the world" and shifting the priority to an ethical consideration of the man and his past, present and future. I would argue that Steinbauer was justified in making the film, not because of the hilarity it produced, but because of the relationship he seems to have developed along the way. Winnebago Man is an excellent example of how the theory laid out above becomes translated into actual practice and ethics on the ground. The representation of Rebney, or any subject in a documentary film, photograph, or written monograph, is inextricable from ethical practices. When producing the image or written word, what type of relationship are you representing? Are you adopting an approach that fetishizes the subject and creates a world for them in which the filmmaker does not exist? In this case, the film portrays an individual that has no interaction with the filmmaking crew and thus creates the illusion that the subject cannot exercise his or her agency when moving through his or her surroundings. Or, do you take a more reflexive, participatory approach? Steinbauer opted for the latter, wherein he made no pretensions that he was invisible and made it clear from the beginning that Rebney was not a passive subject moving through the world, but one actively

${ }^{5}$ David MacDougall, however, has argued against this polarization, writing that observation is, and always has been, not the opposite of, but a component of a participatory, reflexive approach (2003 [1994]: 128-130). 
interrogating his surroundings, which included, first and foremost, the filmmaking crew. In other words, style is inextricable from theory (Howes 2003, 27); both have a significant impact on how one's subject is represented to the world.

\section{Gates of Heaven}

Errol Morris' film Gates of Heaven (1987) provides a second example that makes a strong case for the construction of documentary footage bordering on fictionalization, similar to the kind Flaherty practiced. There is one scene in particular that has caused some controversy, known as the "trophy room". In it, a man sits behind his desk, surrounded by an inordinate amount of trophies, as he ruminates on the significant meaning they hold for him, their inspiration for his work, and how he came to have them. In the more recent documentary film Capturing Reality (Ferrari, 2008), a National Film Board venture, Morris admits that the trophy room was entirely constructed; it did not exist at all. Morris and his crew found the trophies in a dusty attic, brought them into a studio and created a set in which they placed the man. This is not unlike Flaherty's creation of the halved igloo. This type of "reenactment" involves creating a world for one's subjects and filming how they react to it: an intense provocation, designed to elicit something more than (potentially) superficial observation. Morris has remarked that, when making a film, truth is not discovered; it is constructed (see Bloom 2010). His remark clearly denounces a purely observational approach that attempts to uncover a truth already embedded in society. Rather, it acknowledges that truths are processual, coconstructed, and they must be wrung from the cloth of social relations.

Morris seemed to succeed in bringing out of the man sitting in the trophy room something deep inside him: who he wanted to be, or who he thought he really was. For Morris, it seems this is an even greater truth than he would have achieved otherwise, by filming the man as if the camera was invisible, intangible, and unaffecting. The subjectivity of this situation, even if it was not explicitly relayed to the audience, indicates a specific underlying epistemological stance: truth is not objective. It must be created, and the camera is an integral component of this construction. This truth is constructed with the participation of the subject, acknowledging that he or she is a living, breathing, agentic human being that does in fact interact with his or her surroundings, rather than a passive creature one can film and explain without being seen.

\section{Heryog and Ecstatic Truth}

Werner Herzog is famous for blurring the boundary between fact and fiction in his films. As he has said, "I have never made a distinction between my feature films and my 'documentaries'. For me, they are all just films" (Cronin 2002, 95). Instead, Herzog often makes the interesting distinction between fact and truth. In his "Minnesota Declaration" of 1999, a manifesto for documentary filmmakers, he declares that cinéma vérité "is devoid of vérité. It reaches a merely superficial truth, the truth of accountants." This is not to say that Herzog is not in favor of reflexivity and participatory filmmaking. He features prominently in all of his films, clearly interacting with his subjects. Rather, he thinks that it is an illusion that we may access truth simply by revealing how we are implicated in creating the film. We must go beyond this, he thinks, and turn to fictionalization in order to arrive at a deeper meaning, an essence, as he is fond of calling it. This is not unlike Jean Rouch's $(2003,6)$ own statement that "fiction is the only way to penetrate reality." Herzog calls this deeper meaning "ecstatic truth", and it is practiced not just in filmmaking, but also even in mainstream academia. This notion of truth necessarily involves manipulating footage (or data). Yet, even if you are writing an academic paper, this is what you are doing. Writing involves synthesizing ma- 
terial and manipulating it in a certain way in order to bring it together and offer a fresh perspective, or to argue a point that would not necessarily be apparent if you simply left everything the way it was.

So it goes with documentary media. Brian Winston, in particular, has written on the difficulty of implementing a strategy such as Herzog proposes, because in films this idea is often manifested in reenactments or in changes to the chronology of the events filmed in order to make a point or shed light on something that otherwise would not have been apparent (see Winston 2000, 36). Yet, if you take as the basic premise that documentary media portrays a subjective interpretation of events, and is not, and never could have been, striving for an objective representation of unmediated reality (what accountants are after, in Herzog's mind), then many of the criticisms against such strategies lose footing. Much of the uproar over reenactment of the kind Flaherty utilized is based on a vestigial epistemological understanding of film: the assumption that the camera is a mirror that does not lie. But we know now this is not quite accurate, as Winston (2000, 166) remarks: "The camera can most assuredly lie. Indeed, it can do no more than tell $a$ truth; the truth is beyond it."

Little Dieter Needs to Fly (1998), one of Herzog's earlier documentary films, provides several cases in point that illustrate his concept of the ecstatic truth. The film is a biographical tale about Dieter Dengler, a German soldier who was shot down over Laos in 1966 while flying for the U.S. Navy. After being taken prisoner, forced by his captors to run for days on end to evade enemy fire, then chained inside a bamboo prison, Dengler escaped and lived to tell his tale to Herzog. Dengler reenacts portions of this harrowing experience in the film, directed by Herzog, in order to evoke a feeling. Herzog hired Laotian actors to play Dengler's captors, who "forced" him to run through the jungle, much like he was forced to do in 1966, caus- ing him to relive for the camera some of his feelings of terror and isolation. In addition, at the end of the film, Dieter "recalls" coming home after his torture and having to be put to bed in the cockpit of a fighter jet every night, packed into a cradle of pillows. He remarks that this was the only place he felt safe at night. What is interesting is that this entire scene is completely fabricated. Dengler was never put to bed in a cockpit cradle. Like the trophy room in Gates of Heaven, this situation did not exist. In Herzog's accounting terms, it did not happen. However, Herzog says this is beside the point. His films are about drawing out an essence, and what better way to illustrate the feelings and tribulations Dengler suffered than by creating a world in which these emotions surface for us to grasp? Otherwise, we may never come close to understanding what he went through.

\section{Experience, Not Object}

The above examples contain elements of a more subjective, participatory approach, not just to filmmaking, but to social scientific research in general. They privilege a methodology inextricable from an ontological and epistemological position that assumes knowledge is co-constructed in a process of doing social relations; that people are not passive beings that one can observe while remaining unseen oneself, but are instead agentic individuals that interact with their surroundings in a meaningful way. As a result, I argue that the priority of a documentary film, photograph, or written essay should rest more with the participant of the study than with the audience. This is not to say the audience is unimportant; it plays a significant role itself, but this role, as Vivian Sobchack elucidates, can be quite difficult to discern.

Sobchack $(1999,249)$ writes that documentary film in particular should be interpreted as an experience rather than an object. A documentary film, in this sense, is not a thing, but a learning experience; a very short apprenticeship of comprehension. Sobchack advocates for a phenomenological approach 
to theorizing documentary, one that recognizes that everyone's viewing experience is subjectively situated, much like the very process of making the film. This recognition can make it incredibly difficult to discern how any given audience member will respond to a film, as this response depends entirely upon their past experiences and the way in which these experiences will affect their means of interpretation (Sobchack 1999, 247). The film is not a passive object from which one can leach meaning, but rather something one must work to construct in the moment: truth thus becomes something made, and entirely subjective.

One conclusion to draw from this model of "cinematic identification" is the indeterminacy of audience reception (see MacDougall 1998, 69; MacDougall 2006, 19). ${ }^{6}$ Again, I do not recommend ignoring the audience altogether, but I believe that if audience reception is so hard to predict, then (often scant) resources should instead be focused on the relationship with (and ethical responsibility towards) one's subjects. It is safe to say these are the individuals that will be directly affected by the film in measurable ways, both during and after its production. The audience is often an unseen, vaguely conceptualized entity that, to be frank, may not care in the least if a film portrays so-called "objective" truth or not: "Unlike the audience, the vast majority of which remains usually unaffected (in measurable ways, at least) by any documentary it sees, participants are engaged in an exercise that could be life-changing" (Winston 2000, 158).

This paper provides examples of filmmakers and films that have paid attention to the relationship between researcher and participant in meaningful and ethical ways. Winnebago Man, a more overt example, makes explicit this relationship, whereas the trophy room scene in Gates of Heaven implicitly re- veals underlying ethical assumptions. If one takes as a first principle that the camera does not uncover "Truth", but rather any number of constructed truths, a panoply of documentary techniques, such as reenactment and a degree of fictionalization, become viable options for exploring ethnographic situations. As Flaherty once said: "Sometimes you have to lie. One often has to distort a thing to catch its true spirit" (cited in Rotha 1983). Of course, these techniques are useful only insofar as the subjects of the study are comfortable with them, and this should always be the measure of whether or not an ethical relationship is on the right track. At the very least, consideration of the issues presented in this paper may preempt your subjects from screaming at you to get your camera out of their faces.

\section{REFERENCES}

Asch, Тiмотнy. 1975. The Ax Fight. DER. 30 mins.

Banks, Marcus. 2001. Visual Methods in Social Research. London: Sage.

Barbash, Ilisa and LuCien Taylor. 1997. Cross-Cultural Filmmaking: A Handbook for Making Documentary and Ethnographic Films and Videos. Berkeley: University of California Press.

Bateson, Gregory and Margaret Mead. 1942. Balinese Character: A Photographic Analysis. New York: The New York Academy of Sciences.

. 1976. "For God's Sake Margaret: Conversation with Gregory Bateson and Margaret Mead." Electronic document, www.oikos.org/forgod.htm, accessed June 8, 2011.

Bloom, Livia. 2010. Errol Morris: Interviews. Jackson: University Press of Mississippi.

Castañeda, Quetzil 2006. "The Invisible Theatre of Ethnography: Performative Principles of Fieldwork." Anthropological Quarterly 79(1):75-104.

\footnotetext{
${ }^{6}$ For a study that explored unexpected, aberrant readings to ethnographic films that caused some controversy in the 1990's, see Martinez 1990.
} 
Cronin, Paul. 2002. Herzog on Herzog. London: Faber.

Druick, ZoË. 2010. Allan King's A Married Couple. Toronto: University of Toronto Press.

Ferrari, Pepita. 2008. Capturing Reality. National Film Board of Canada. 90 mins.

FlaHerty, Robert. 1922. Nanook of the North. Revillon Frères: USA. 70 mins.

-1926. Moana: A Romance of the Golden Age. Paramount Pictures: USA. 64 mins.

. 1934. Man of Aran. Gaumont-British Picture Corporation Ltd. 77 mins.

Gardner, Robert. 1985. Forest of Bliss. Film Study Center, Harvard University. 91 mins.

Gray, Gordon. 2010. Cinema: A Visual Anthropology. Oxford: Berg.

Grimshaw, Anna. 2001. The Ethnographer's Eye: Ways of Seeing in Modern Anthropology. Cambridge: Cambridge University Press.

. 2011. "The Bellweather Ewe: Recent Developments in Ethnographic Filmmaking and the Aesthetics of Anthropological Inquiry." Cultural Anthropology 26(2):247262.

Herzog, Werner. 1998. Little Dieter Needs to Fly. Werner Herzog Filmproduktion. 80 mins.

1999. Minnesota Declaration. Walker Art Centre, Minnesota.

Howes, David. 2003. Sensual Relations: Engaging the Senses in Culture and Social Theory. Ann Arbor: University of Michigan Press.

JaCkson, John L. 2005. Real Black: Adventures in Racial Sincerity. Chicago: University of Chicago Press.

King, Allan. 1969. A Married Couple. Aquarius Films. 97 mins.

Loizos, Peter. 1997. "First Exits from Observational Realism: Narrative Experiments in Recent Ethnographic Films." In Rethinking Visual Anthropology, edited by Marcus Banks and Howard Morphy. New Haven and London: Yale University Press. MacDougall, David and Judith MacDougall. 1991. Photo Wallahs. Fieldwork Films/La Sept. 60 mins.
MacDougall, David. 1992. "Photo Wallahs: An Encounter with Photography." Visual Anthropology Review 8(2):96-100. 1994. "Whose Story Is It?" In Visualizing Theory, edited by Lucien Taylor. New York and London: Routledge. 1998. Transcultural Cinema. Princeton: Princeton University Press. - 2003 [1994]. "Beyond Observational Cinema." In Principles of Visual Anthropology, edited by Paul Hockings. Berlin and New York: Mouton de Gruyter.

. 2006. The Corporeal Image: Film, Ethnography, and the Senses. Princeton: Princeton University Press.

Malinowski, Bronislaw. 1967. A Diary in the Strict Sense of the Term. New York: Harcourt, Brace \& World, Inc.

Martinez, Wilton. 1990. "Critical Studies and Visual Anthropology: Aberrant vs. Anticipated Readings of Ethnographic Film." Society for Visual Anthropology Review Spring:34-47.

Massot, Claude. 1990. Nanook Revisited. IMA Productions. 60 mins.

Mead, Margaret. 2003 [1974]. "Visual Anthropology in a Discipline of Words." In Principles of Visual Anthropology, edited by Paul Hockings. Berlin and New York: Mouton de Gruyter.

Mauss, Marcel. 1990 [1950]. The Gift: The Form and Reason for Exchange in Archaic Societies. New York and London: W. W. Norton.

Maysles, Albert, David Maysles and CharLotte Zwerin. 1969. Salesman. Maysles Films. 90 mins.

Morin, Edgar and Jean Rouch. 1960. Chronique d'un été. Argos Films. 90 mins.

Morris, Errol. 1978. Gates of Heaven. New Yorker Films. 85 mins.

Pink, SARAh. 2006. The Future of Visual Anthropology: Engaging the Senses. London and New York: Routledge.

Rotha, Paul. 1983. Robert J. Flaberty: A Biography, edited by Jay Ruby. Philadelphia: University of Pennsylvania Press. 
Rouch, Jean. 2003. Ciné-Ethnography, edited by Steven Feld. Minneapolis: University of Minnesota Press.

RubY, Jay. 1975. "Is an Ethnographic Film a Filmic Ethnography?" Studies in the Anthropology of Visual Communication 2(2):104111.

. 2000. Picturing Culture: Explorations of Film and Anthropology. Chicago: University of Chicago Press.

Simpson, Audra. 2003. "To the Reserve and Back Again: Kahnawake Mohawk Narratives of Self, Home and Nation." PhD Dissertation, McGill University, Montreal. - 2007. "On Ethnographic Refusal: Indigeneity, 'Voice' and Colonial Citizenship." Junctures 9:67-80.

Sobchack, Vivian. 1999. "Toward a Phenomenology of Nonfictional Film Experience." In Collecting Visible Evidence, edited by Jane M. Gaines and Michael Renov. Minneapolis: University of Minnesota Press.

Steinabuer, Ben. 2009. Winnebago Man. Kino International. 85 mins.

Strathern, Marilyn. 1987. "Out of Context: The Persuasive Fictions of Anthropology." Current Anthropology 28(3):251281.

Tedlock, Barbara. 1991. "From Participant Observation to the Observation of Participation." Journal of Anthropological Research 47(1):69-94.

Weinberger, Eliot. 1994. "The Camera People." In Visualizing Theory, edited by Lucien Taylor. New York and London: Routledge.

Winston, Brian. 2000. Lies, Damn Lies and Documentaries. London: BFI Publishing. Wiseman, Frederick. 1970. Hospital. OSTI. 84 mins. 